\title{
Foundation phase teachers' interpretation of the life skills programme with regard to the teaching of natural science
}

\begin{tabular}{|c|c|}
\hline \multicolumn{2}{|c|}{$\begin{array}{l}\text { Authors: } \\
\text { Saritha Beni }{ }^{1} \\
\text { Michele Stears }{ }^{2} \\
\text { Angela James }^{2}\end{array}$} \\
\hline $\begin{array}{l}\text { Affiliations: } \\
{ }^{1} \text { Department } \\
\text { Education, Em } \\
\text { of Education, }\end{array}$ & $\begin{array}{l}\text { Science } \\
\text { bury Institute } \\
\text { South Africa }\end{array}$ \\
\hline \multicolumn{2}{|c|}{$\begin{array}{l}{ }^{2} \text { Mathematics and Computer } \\
\text { Science Education } \\
\text { Department, School of } \\
\text { Science and Technology } \\
\text { Education, University of } \\
\text { KwaZulu-Natal, South Africa }\end{array}$} \\
\hline \multicolumn{2}{|c|}{$\begin{array}{l}\text { Corresponding author: } \\
\text { Saritha Beni, } \\
\text { sarithabeni@telkomsa.net }\end{array}$} \\
\hline \multicolumn{2}{|c|}{$\begin{array}{l}\text { Dates: } \\
\text { Received: } 29 \text { Apr. } 2016 \\
\text { Accepted: } 16 \text { Feb. } 2017 \\
\text { Published: } 31 \text { May } 2017\end{array}$} \\
\hline \multicolumn{2}{|c|}{$\begin{array}{l}\text { How to cite this article: } \\
\text { Beni, S., Stears, M. \& } \\
\text { James, A., 2017, 'Foundation } \\
\text { phase teachers' interpretation } \\
\text { of the life skills programme } \\
\text { with regard to the teaching of } \\
\text { natural science', South African } \\
\text { Journal of Childhood } \\
\text { Education 7(1), a440. https:// } \\
\text { doi.org/10.4102/sajce. } \\
\text { v7i1.440 }\end{array}$} \\
\hline \multicolumn{2}{|c|}{$\begin{array}{l}\text { Copyright: } \\
\text { (C) 2017. The Authors. } \\
\text { Licensee: AOSIS. This work } \\
\text { is licensed under the } \\
\text { Creative Commons } \\
\text { Attribution License. }\end{array}$} \\
\hline \multicolumn{2}{|c|}{ Read online: } \\
\hline 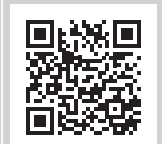 & $\begin{array}{l}\text { Scan this QR } \\
\text { code with your } \\
\text { smart phone or } \\
\text { mobile device } \\
\text { to read online. }\end{array}$ \\
\hline
\end{tabular}

Scientific literacy should be promoted through the teaching of science from Grade $\mathrm{R}$ and for this to happen, teachers need to understand what science should be taught and how it should be taught. This interpretive, qualitative study explores the degree to which four foundation phase teachers interpret the life skills programme with regard to the teaching of natural science by using an adapted version of a theory of implementation. Analyses of a questionnaire, documents (Revised National Curriculum Statement and lesson plans) and interviews enabled us to build a picture of how each teacher interpreted the curriculum with regard to a number of constructs. The findings show that foundation phase teachers have great difficulty interpreting the curriculum because the foundation phase curriculum does not give clear guidance with regard to the teaching of science. Their poor content knowledge, the poor understanding of what integration of science in numeracy and literacy entails, as well as their poor understanding of the instructional methods used to teach science exacerbate the problem.

\section{Introduction and background}

The foundation phase in South Africa constitutes the latter four years of early childhood development (the initial stage of development from birth to nine years) and thus the initial stage of schooling (Department of Basic Education DBE, 2011). This is where the 'foundation for further learning is laid' (Department of Education 2003:19) and where learners' love for science should start and be nurtured so that they may develop a curiosity about the world and become critical thinkers (DBE 2011).

With the introduction of a democratic dispensation in South Africa, a curriculum known as Curriculum 2005 (C2005) which was 'committed to OBE' (outcomes-based education) (Maphalala 2006:2) was introduced. From its inception, complications plagued the process of implementation of C2005. This led to a number of revisions of the curriculum that culminated in the Curriculum and Assessment Policy Statement (CAPS, DBE 2011). At the time when this research was conducted, the revised curriculum statement (South Africa, DoE 2002) was in use. This statement contained two documents that made reference to the foundation phase. One was the foundation phase curriculum and the other was the natural science learning area statement that spelt out what science should be taught in the foundation phase.

According to the Revised National Curriculum Statement (RNCS) (South Africa, DoE 2002), the life skills learning programme in the foundation phase as well as the natural science learning area statement promoted scientific literacy. Foundation phase teachers therefore had to take cognisance of two policy documents that provided guidance concerning the teaching of science and these effectively constituted two curricula. While the RNCS (South Africa, DoE 2003) had natural science as a mandatory component of the life skills learning programme, with scientific investigations promoted (South Africa, DoE 2002), it failed to clearly define how scientific investigations may be integrated within the three foundation phase programmes. This appears to be a problem in other countries as well. For example, Marques et al. (2014), in their report for policymakers and stakeholders in Portugal (European Union Seventh Framework Programme FP7, 2007-2013), allude to the fact that the guiding principles of the curriculum expect teachers to direct the process of teaching and learning in such a way that learners become active observers with the ability to discover, investigate and experiment. Unfortunately, the curriculum for basic education provides no guidance as to the types of activities foundation phase teachers could introduce to promote the skills mentioned above. 
Currently, the curriculum includes a section referred to as ‘Beginning Knowledge' (South Africa, DBE 2011) which consists of components from, among others, the social sciences as well as the natural sciences. It makes clear reference to knowledge of scientific concepts and acquisition of a number of process skills, including 'experimenting' (p. 8). While guidance is provided with regard to the topics that should be taught in each grade, it does not elaborate on how skills should be taught, providing very little guidance for foundation phase teachers. It is in light of this that we believe this research is still relevant as the challenges presented by the RNCS appear to persist in the CAPS.

\section{A framework for interpretation}

A number of factors may affect the way teachers interpret the curriculum. Rogan and Grayson (2003) proposed a theory of implementation to assist researchers in determining exactly where a teacher is located with regard to his or her ability to implement a science curriculum. This is accomplished by developing criteria for four levels, where level 1 indicates the least competence and level 4 the highest competence. We adapted this theory to include interpretation as well as implementation, and this research reports only on interpretation. We identified four constructs that could indicate how teachers interpret the curriculum. These are time allocated for natural science in the foundation phase, integration of natural science with other learning areas in the foundation phase, natural science content that should be taught and the instructional methods used to teach natural science. This approach allowed us to place each teacher at a particular level with regard to his or her interpretation of the curriculum. The link between these four constructs and the interpretation of the science curriculum is shown in Figure 1.

As this study attempts to discover how foundation phase teachers interpret the curriculum with regard to the teaching of natural science in the foundation phase, these four constructs were used as a lens through which teachers' interpretations were explored. The research question that guided the study was: How do foundation phase teachers interpret the curriculum with regard to time allocated to the teaching of natural science, integration of natural science in other learning areas, science content to be taught and methods that should be employed in teaching natural science?

We interrogated each of these factors separately to determine how teachers understood their meaning and how they collectively contributed to teachers' interpretation of the natural science curriculum.

\section{Literature review}

Globally, the main aim of science education is to produce a scientifically literate citizenry that are able to think critically and solve problems. Goodrum, Hackling and Rennie (2001) confirm that science education ought to provide learners with scientific knowledge and concepts, scientific process skills and scientific values and attitudes, to enable them to manage in a scientific and technological world. This entails the development and nurturing of an interest in and love for science from the time the child enters the schooling system in Grade R.

The way in which science is taught at primary school level has the ability to be a catalyst in developing learners' interest in the sciences (Harlen 2000; Rocard et al. 2007). The importance of an effective science curriculum, particularly a foundation phase curriculum that achieves the goals stated above, cannot be underestimated. However, international reviews have raised concerns with regard to science taught in primary school in some instances, highlighting a difference between the intended and the actual curriculum as experienced by learners (Australian Science, Technology and Engineering Council, ASTEC 1997; Department of Education for Northern Ireland, DENI 2002). Campbell and Chittleborough (2014) believe that:

By creating the role of science specialists in primary schools, and investing in science as a specialised knowledge area, science can be promoted, science teaching resources better managed, and teachers who are not confident in science, mentored (p. 19).

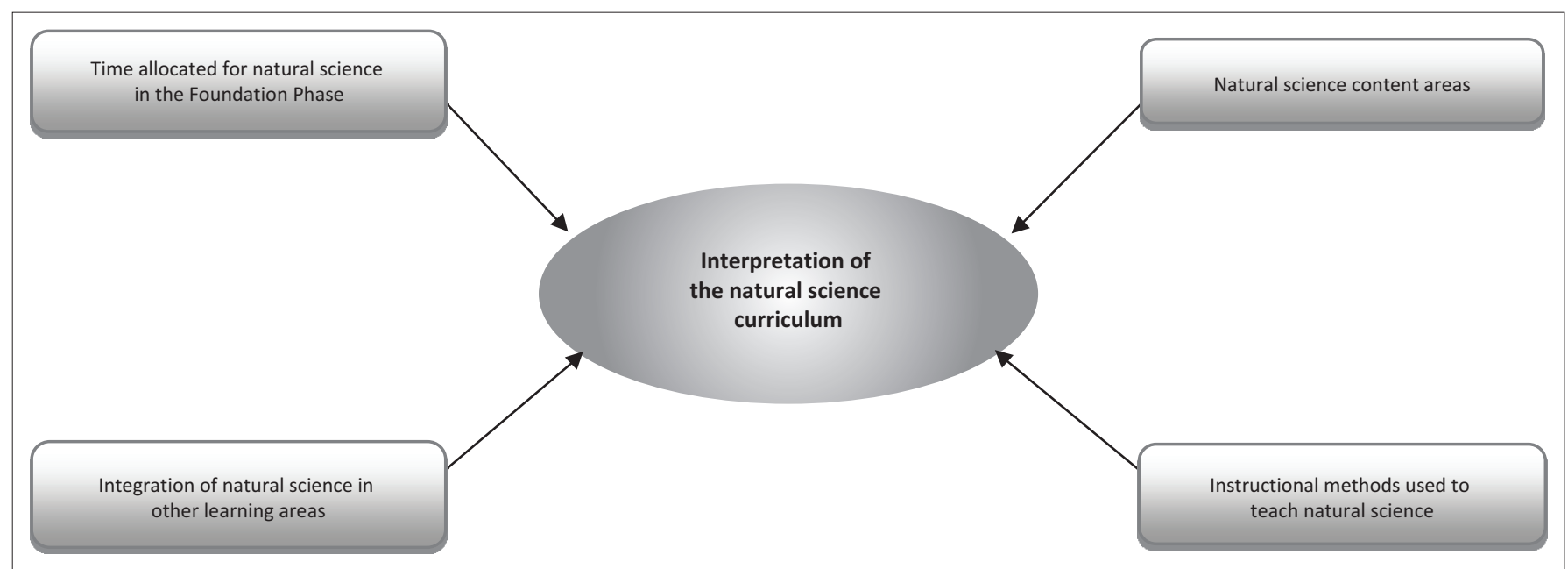

FIGURE 1: Factors that influence teachers' interpretation of the natural science curriculum. 
Lamanauskas (2009) rightfully maintains:

Only high-quality natural science education acquired in primary school can guarantee proper continuation of natural science education in basic and secondary school (p. 7).

Lack of science knowledge, however, influences the teachers' ability to implement appropriate pedagogic strategies to introduce science concepts effectively (Kolokouri \& Plakitsi 2010). A frequent theme in much of the literature about primary science education has been the noticeable reluctance of many teachers to teach science (Appleton 2003). Research conducted in schools has identified the fact that science teaching is challenging, with teachers either depending on a 'specialist' teacher to teach science lessons or avoiding science teaching because of feelings of inadequacy as teachers of science (Appleton 2003; Hackling, Peers \& Prain 2007; Southerland, Sowell \& Enderle 2011; Tosun 2000; Tytler 2009). Fleer (2009) is of the view that it is not only the teachers' lack of scientific knowledge that influences their confidence and competence in science teaching but also their philosophy of teaching and their teaching practices. Teachers' views on how young children learn have a significant impact on the learning of science (Fleer 2009). Sachs (2001:153) is of the view that 'policy image' of teachers makes demands that conflict with their 'personal identities' as practitioners. For example, foundation phase teachers may see themselves as general practitioners in this phase and not as science specialists and as a result will not easily change their identities. Jansen (2001:242) maintains, 'This identity conflict might lie at the heart of the implementation dilemma in educational reform'. He proposes a theoretical plan that endorses a profound examination of the 'personal identities' of teachers in the 'context of developing countries, given the complex problems associated with teacher education reform in such contexts' (Jansen 2001:242). When science is taught at primary school level, teachers need to ensure that it is taught using relevant methodology. Harlen (2008) is of the view that:

To achieve the aims of Science Education at the primary school level it is important to consider not just the subject matter that is suitable for the development of scientific understanding, but also the pedagogy that is required for meeting these aims. (p. 17)

A study conducted by Rocard et al. (2007) revealed that inquiry-based methodologies have a positive effect on learners' achievement in science. Inquiry-based learning is also regarded as an appropriate method to encourage an interest in science according to Petre (2013). At the foundation phase level, the teacher's role is crucial as he or she has to judge the extent to which his or her learners are able to engage in inquiry-based learning activities by determining how the experiences are to be structured. The teacher should plan learning experiences that engage and challenge children in thinking that is conceptually rich, coherently organised and persistently knowledge building (Garbett 2003). An effective early childhood teacher is one who can facilitate and extend children's learning within the holistic nature of the early childhood curriculum (Beni, Stears \& James 2012). Rocard et al. (2007) also found that learners from disadvantaged backgrounds and low levels of self-confidence have benefitted from inquiry-based methodologies.

According to Van Aalderen-Smeets, Van Der Molen and Asma (2012):

Many initiatives across the world have focused on increasing the scientific knowledge, inquiry skills, and attitudes of primary school students by allocating more time to science education (p. 162).

This does not appear to be the case in South Africa. Currently, there is a strong move in South Africa towards improving basic reading, writing and mathematical skills (Department of Education 2008). The fact that the RNCS advocates the integration of natural science within the life skills learning programme, which in turn has to be integrated in the foundation phase curriculum, which includes numeracy and literacy, means that very little time is allocated to the teaching and learning of science as only $25 \%$ of teaching time is allocated to life skills (which includes six learning areas) (Department of Education 2011). This is a concern, as inquirybased learning requires time.

\section{Methodology}

This research is located within an interpretive paradigm, as we attempted to understand teachers' interpretation of the natural science curriculum within the foundation phase learning programme. We implemented a qualitative research approach as it is concerned with describing and understanding trends in the teachers' natural context, which in this study is the classroom, with the aim of developing meanings imparted by the teachers.

The research site for this study was an urban school. Four foundation phase teachers from Grades $\mathrm{R}$ to 3 participated in the research. The four teachers were all female and were given the pseudonyms Karen, Fiona, Carly and Simone. Karen taught Grade R, Fiona Grade 1, Carly Grade 2 and Simone Grade 3. All four participants were assured that all information provided would be treated with the utmost confidentiality and informed that they could withdraw from the study at any point if they so wished. The project was granted ethical clearance by the institution where the researchers were located (ethical clearance number HSS/0922/09D).

The instruments used to collect data included document analysis, a questionnaire (Appendix 1) and semi-structured interviews. The analysis of the curriculum served as a benchmark for comparing what teachers do. Although there were only four participants in this study, we decided to administer a questionnaire (to allow the participants to provide information in the questionnaire in their own time). We designed the questionnaire to include both closed-ended and open-ended questions. The closed questions provided a range of responses from which the participants could choose. Some of the closed questions supplied the participants with choices, for example content areas and frequency of instructional methods, where the participants were required 
to select the most appropriate one. The open-ended questions revealed the participants' responses at a deeper level by allowing them to explain their responses. An addendum was attached to the questionnaire, which clarified what was meant by each instructional method. This was done so that there would be a common understanding of the instructional methods. Participants could select the frequency of use from daily, weekly, fortnightly, monthly or once a term.

A composite table (Appendix 2) was constructed, showing the competence at each level with regard to the four constructs. This enabled us to place each teacher at a particular level with regard to her ability to interpret the curriculum.

\section{Findings and discussion}

The findings that enabled us to answer our research question are discussed within the framework of the four constructs indicated in Figure 1.

\section{Time allocated for natural science}

Natural science forms part of the life skills learning programme and thus the time allocated was the time allocated for this programme and not natural science specifically. All teachers used set lesson plans taken from supporting documents (Foundations for Learning) provided by the education department. Table 1 shows the comparison of the allocation of times according to the time Karen said she spent on teaching life skills, what the curriculum documents stated and her lesson plans.

The time Karen stated verbally that she allocated to life skills is in keeping with the curriculum documents. However, the time allocated on the lesson plans for life skills had no time allocation and therefore the time allocated to natural science could not be verified.

Table 2 shows the comparison of the allocation of times according to Fiona's responses and the curriculum documents for life skills.

The time Fiona stated verbally that she allocated to life skills is in keeping with the curriculum documents. However, she submitted no lesson plan for life skills and this made it impossible to determine the time apportioned to natural science.

TABLE 1: Comparison of the allocation of times in different sources in Karen's case.

\begin{tabular}{llcc}
$\begin{array}{l}\text { Learning } \\
\text { programme }\end{array}$ & $\begin{array}{l}\text { Foundations for Learning } \\
\text { Lesson plans }\end{array}$ & $\begin{array}{l}\text { Curriculum } \\
\text { documents }\end{array}$ & Karen \\
\hline Life skills & $\begin{array}{l}\text { Overview of all life skills } \\
\text { activities with no time allocation }\end{array}$ & $1 \mathrm{~h} 10 \mathrm{~min}$ & $1 \mathrm{~h} 10 \mathrm{~min}$ \\
$\begin{array}{l}\text { Additional } \\
\text { activities }\end{array}$ & $1 \mathrm{~h} 30 \mathrm{~min}$ & & \\
\hline
\end{tabular}

TABLE 2: Comparison of the allocation of times in different sources in Fiona's case.

\begin{tabular}{llcc}
\hline $\begin{array}{l}\text { Learning } \\
\text { programme }\end{array}$ & $\begin{array}{l}\text { Foundations for Learning } \\
\text { Lesson plans }\end{array}$ & $\begin{array}{l}\text { Curriculum } \\
\text { documents }\end{array}$ & Fiona \\
\hline Life skills & No lesson plan given & $1 \mathrm{~h} 10 \mathrm{~min}$ & $1 \mathrm{~h} 10 \mathrm{~min}$ \\
\hline
\end{tabular}

Table 3 shows the comparison of the allocation of times according to Carly's responses and the curriculum documents for life skills.

The time Carly stated that she allocated to life skills is in keeping with the curriculum documents. However, in the absence of the life skills lesson plans, no comparison could be made with what Carly stated.

Table 4 shows the comparison of the allocation of times according to Simone's responses and the curriculum documents for life skills.

The time Simone stated that she allocated to life skills was slightly different from that stipulated in the curriculum documents. In the absence of the life skills lesson plans, no comparison could be made with Simone's statement.

The curriculum, and especially supporting documents such as the Foundations for Learning, foreground numeracy and literacy, which seems to suggest to teachers that life skills are less important. A further complication is the fact that the foundation phase curriculum and the Foundations for Learning documents (which are official departmental documents) allocate different times to different programmes. The fact that Fiona, Carly and Simone did not develop lesson plans for life skills indicated that they placed less emphasis on this learning programme than on numeracy and literacy for which they developed lesson plans. None of the teachers consulted the natural science curriculum for guidance with regard to how much time should be allocated to the given topics in the curriculum. Furthermore, the fact that the foundation phase curriculum made no attempt to guide teachers as to the time they should allocate to the different learning areas within the life skills learning programme reinforced the view as expressed by Fiona 'So basically Maths and Numeracy is more important than anything else' that these learning areas, of which natural science is one, are less important components of the foundation phase curriculum.

\section{Integration of natural science in other learning areas}

This construct refers to teachers' understanding of what the curriculum expected of them with regard to the integration of natural science in other learning areas. Karen said she brought in natural science any time into her lesson 'because they [the Department of Education] say we must integrate it'. However, she did not think the curriculum provided sufficient opportunities to teach natural science and believed 'we could

TABLE 3: Comparison of the allocation of times in different sources in Carly's case.

\begin{tabular}{llcc}
\hline $\begin{array}{l}\text { Learning } \\
\text { programme }\end{array}$ & $\begin{array}{l}\text { Foundations for Learning } \\
\text { Lesson plans }\end{array}$ & $\begin{array}{l}\text { Curriculum } \\
\text { documents }\end{array}$ & Carly \\
\hline Life skills & No lesson plan given & $1 \mathrm{~h} 10 \mathrm{~min}$ & $1 \mathrm{~h} 10 \mathrm{~min}$ \\
\hline
\end{tabular}

TABLE 4: Comparison of the allocation of times in different sources in Simone's case.

\begin{tabular}{llcc}
\hline $\begin{array}{l}\text { Learning } \\
\text { programme }\end{array}$ & $\begin{array}{l}\text { Foundations for Learning } \\
\text { Lesson plans }\end{array}$ & $\begin{array}{l}\text { Curriculum } \\
\text { documents }\end{array}$ & Simone \\
\hline Life skills & No lesson plan given & $1 \mathrm{~h} 10 \mathrm{~min}$ & $1 \mathrm{~h} 15 \mathrm{~min}$ \\
\hline
\end{tabular}


do with more of $i t^{\prime}$ as in 'Grade R only certain things are touched on'. Karen said that the teachers 'don't sit down and say this is science we are doing', rather 'a lot of it is integrated into everything else'. Karen admitted that sometimes the 'science is lost during the integration' with the other learning areas. From Karen's response, it is apparent that she was clearly mindful that natural science was supposed to be taught by integrating it into the learning programmes. However, by integrating natural science, she was unsure of how often she taught natural science in her class.

Analysis of Karen's life skills lesson plans provided information with regard to what was planned for each day. This analysis gave an indication of Karen's interpretation with regard to where natural science fits in the particular section covered during observation. The theme for the period of observation was 'friends'. This theme successfully integrated literacy and art, as well as numeracy to a degree, but there was no evidence of activities that related to science. She made reference to health aspects as an example of the science she taught, but this topic, drawn specifically from the life orientation curriculum, was not a particularly good example of natural science integration.

Furthermore, the topics in the Foundations for Learning lesson plans covered during the period of observation were not helpful in assisting teachers to integrate natural science, and a teacher like Karen, who was not confident in teaching natural science, was not able to manage such integration.

Fiona held strong views on how she believed natural science should be taught. During her interview, she elaborated:

'Besides just being a lesson on its own, it should be integrated in everything because science is around us, look around us and there is science in everything. It shouldn't be only integrated.' (Fiona, Female, Grade 1 Teacher, 44 years old)

Fiona made a case for learners learning natural science from an early age as it is all around them. She admitted that if she was conscious of it, she taught natural science once a week in her class, if not, it would have been part of the lesson incidentally. From Fiona's admission, it was very difficult to ascertain how often she taught natural science, as she did not know this herself. Her views on whether the curriculum promoted natural science were forceful as she responded 'Oh no! Absolutely not, never, never'.

Fiona indicated that she taught natural science in 'both ways', that is, by integrating natural science in numeracy and literacy and by integrating numeracy and literacy in natural science. She provided an example:

'For instance water and finding out how many cups of water you get from a two litre. That is Science and the water. The science of it, right? The capacity, cups, counting, data handling that's all.' (Fiona, Female, Grade 1 Teacher, 44 years old)

The activity was a numeracy lesson in which Fiona's lesson plan integrated measurement and data handling, which are concepts learnt in both numeracy and natural science.
Fiona's lesson plans did not provide direct information either on how she interpreted the curriculum or where natural science was addressed. In both the numeracy and literacy lesson plans, there was no sign of natural science integration and no lesson plan for life skills was presented. Fiona's inability to provide appropriate examples showing how she integrated natural science showed she did not have a clear understanding of what integration meant. The example of the water puddle could be construed as integrating literacy into natural science but there was no evidence of learners engaging in an investigation. It was clear that Fiona was also unaware of the natural science curriculum for the foundation phase and therefore she did not know what science should be taught in Grade 1.

Carly did not believe that the curriculum offered sufficient opportunities to teach natural science in the foundation phase, although it promoted natural science 'to a certain extent'. Carly stated, 'Science is incorporated in all the other learning areas and not just taught separately'. Carly admitted, 'I haven't tried doing science on its own'. During the interview, Carly stated that she knew that other learning areas needed to be integrated into the three learning programmes, literacy, numeracy and life skills. In both the numeracy and literacy lesson plans, there was no sign of natural science integration and no lesson plan for life skills was presented. Carly was also unaware of the natural science curriculum for the foundation phase and therefore she did not know what science should be taught in Grade 2. She stated that she was fully aware that natural science had to be taught through integration with other learning programmes, but was not confident doing it as she needed to be shown how to do it. She said that she tried to integrate natural science but could not account for the time she spent teaching natural science.

Although Simone was of the view that numeracy and literacy should be integrated with natural science, she admitted, 'At the moment we are doing it the other way around'. Even though Simone believed the curriculum promoted natural science 'in a very subtle way', she found it difficult to discover the natural science content within the curriculum. She clarified, 'You see if I was science driven as a teacher then maybe I will pick up the aspects of science easier, but because I am not, it is hard to find it'. Simone was of the opinion that the curriculum did not offer sufficient opportunities to teach natural science and admitted, 'Science is not something we really expose our learners to'. She went on to say, 'We supposed to integrate it into our learning areas but we don't really have the equipment'.

As Simone did not have the aptitude for science teaching, she experienced difficulty in identifying the science content in the curriculum. This was very important to note as it implied that the structure of the curriculum was not designed in an accessible manner for all teachers. Simone's inability to provide appropriate examples of how she integrated natural science showed that she did not have a clear understanding 
of what integration meant. As was the case with Fiona and Carly, Simone's lesson plans did not provide direct information on how she interpreted the curriculum or where natural science was addressed. In both the numeracy and literacy lesson plans, there was no sign of natural science integration and no lesson plan for life skills was presented. Simone was also unaware of the natural science curriculum for the foundation phase and therefore she did not know what science should be taught in Grade 3.

\section{Natural science content areas}

Teachers were asked to indicate from a list which content topics they were very confident, confident, not so confident and not confident at all to teach. While confidence to teach a topic does not necessarily mean that the topic is taught well, it does indicate a teacher's familiarity with the topic and therefore the ability to engage with the topic. We are also of the view that teachers have little confidence to teach topics that they are not familiar with and therefore have little knowledge of those topics. Not all of these topics are meant to be taught in the foundation phase, but we thought it was important to give the teachers the opportunity to select from as wide a range of topics as possible. The topics were taken from the natural science curriculum document.

Karen was very confident to teach the content areas of nutrition, air, weather and water. She did not reveal her confidence levels to teach any other content area that was asked in the questionnaire. Her confidence to teach specific natural science content areas was in relation to the content areas taught within the foundation phase at her school. She only taught what she was required to teach and as such with the continued teaching of the same topic, she became confident to teach them. The content selected was taken from the workbooks and Foundation for Learning curriculum documents and not from the natural science curriculum documents.

Fiona was very confident to teach nutrition, human body systems and water. She was also confident to teach a number of other topics as indicated in the table as well. She was less confident to teach physics topics. Fiona stated during the interview that she was very confident to teach nutrition, air, weather and water 'because we teach this'. Fiona recognised that she was not confident to teach the other topics 'because maybe we don't teach them'. She elaborated, 'I didn't put very confident in knowledge for animals maybe because I do not know all the animals'. Her confidence to teach specific natural science content areas was in relation to the content areas taught within the foundation phase at her school. She was unaware of the natural science curriculum and was guided by the Foundations for Learning books.

Carly did not select any content area that she was very confident to teach. She listed a few topics which she was confident to teach, but was less confident to teach most of the other topics. The content areas she taught often were nutrition, air, weather, water and plants. The reasons she gave for this was:

'It seems to come up a lot depending on our context. Sometimes it does fall in our context, in our lesson planning. Depends on the age group also.... These are the more appropriate depending on the age group of the children, when you are talking about 7 years.' (Carly, Female, Grade 2 Teacher, 34 years old)

It was surprising to note that Carly was not confident in teaching the content areas she taught often (nutrition, air, weather, water and plants), while she was confident in teaching which she was not expected to teach. This may have been because of the fact that the selection of content was a decision made collectively by all the Grade 2 teachers and Carly had to accept this. Carly described herself as not having sound science content knowledge. She was unaware of the natural science curriculum and was guided by the Foundations for Learning books.

Simone appeared to be either very confident to teach some topics or not confident at all to teach other topics. She was very confident in the content areas she taught regularly. The content areas that Simone interpreted as part of the natural science curriculum included animals, nutrition, air, weather and water. Her confidence levels for the content she taught correlated with the content she taught within the foundation phase at her school. She only taught what she was required to teach and as such with the continued teaching of the same topic, she became confident. The content selected was taken from the workbooks and Foundation for Learning curriculum documents and not from the natural science curriculum documents.

The responses from the teachers showed that, with the exception of Carly, they were very confident to teach a limited number of topics such as air, water, weather and nutrition. Given their reasons that they were confident to teach these topics, because they regularly teach them, it appears that the same topics are repeated every year in the different grades, with limited variation. It was also obvious that topics relating to chemistry and physics were not attempted. While it is important to note that the teachers often indicated in interviews that they were not sure exactly what science is, they could select topics they recognised, although they may not have realised before that they were part of the natural science curriculum.

\section{Instructional methods}

Teachers were given a list of instructional methods they used to teach science and asked to select the methods from this list. The instructional methods that Karen indicated she used in her lesson to teach natural science provided insight into her interpretation of the curriculum. She justified her choice as 'these are the methods used to stimulate learners' thinking and imagination'. She did not select investigating as an instructional method, in spite of the fact that the natural science curriculum foregrounded this as one of the essential process skills learners should acquire. From Karen's 
responses, she viewed demonstrations as having a place in the curriculum.

'Just lately, we took water, put some soapy solution in and blew bubbles. We also put sugar or salt in the water and mixed it and the learners could taste this and see which one.' (Karen, Female, Grade R Teacher, 58 years old)

It was not clear which science concept this activity was intended to elucidate. While Karen mentioned that she selected problem-based learning, cooperative learning and project-based learning as instructional methods and used them daily, there was no evidence in her lesson plans of such activities. Karen even did not select demonstrations as an instructional method she used in her teaching. However, during the interview, she cited examples of demonstrations that she used. Furthermore, there was no indication that the science concepts underpinning the demonstrations were taught to the learners.

Fiona selected discussion, problem solving and stories or narratives as instructional methods she used in her daily teaching. She selected role-play, hands-on and simulations as methods she used weekly. She said she used discussions daily, because

'I am a grade one teacher and have learners who are isizulu [speaking] therefore daily discussions are important to improve vocab and also to teach them to speak in logical sequence and good train of thought.' (Fiona, Female, Grade 1 Teacher, 44 years old)

She used a hands-on approach, as 'learners have to be consistently encouraged, motivated and immediately corrected'. She considered hands-on science as 'Me working with the children and them finding out for themselves, like investigations'. During the interview, Fiona elaborated with an example to demonstrate why she selected problem solving as an instructional method she used regularly:

'The reason being is that just the other day we had done capacity with water. At random I put seven, eight, nine, 10 cups ... All the time I just wanted to see how they how they were going to use these cups. They going to have to fill these cups up and let me see how many cups of water you get out of the two litre, one litre. They must write it down and colour it in. Every time they fill in a cup, they must colour it in.' (Fiona, Female, Grade 1 Teacher, 44 years old)

Fiona considered it 'absolutely' important for teachers to use demonstrations. She believed everybody should be shown how to do things. She elaborated:

\footnotetext{
'It starts from even us, people as housewives and in the kitchen needs sometimes, not everybody can use their brains, they need to see a demo. For some children they work with visual stuff and some don't have the capacity to work with just the theory part of it or oral. They have to see it.' (Fiona, Female, Grade 1 Teacher, 44 years old)
}

Fiona's confusion with the instructional methods indicated that she did not have a clear understanding of the different types of instructional methods used. Her apparent confusion with what constitutes problem solving and the related examples confirms this.

During the interview, Carly provided an example from her teaching that showed how she accomplished this:

'You know like when you are doing the plants, you make the children bring the plant, the bean plant we actually experiment and they watch the bean plant growing.' (Carly, Female, Grade 2 Teacher, 34years old)

Carly thought it was important to use demonstrations in teaching natural science, especially 'on this level'.

While Carly mentioned that she selected inquiry, lecture, discussion and hands-on as instructional methods and used them daily, there was no evidence in her lesson plans (numeracy and literacy) of such activities. The example that Carly cited during the interview was a practical activity showing the growth of the bean plant, which was a science content area. However, there was no evidence that the lesson was taught as a practical activity and what science concepts were specifically taught. Carly believed that learners learn more from demonstrations because of their background.

Simone's view was that demonstrations can be 'very effective' in teaching natural science. She believed showing the child an effective method 'so that it will stick in their heads' rather than just telling them to do something. Simone did not select problem solving as an instructional method used by her to teach natural science. However, during the interview, she stated that there was a place for problem solving in the teaching of natural science. She responded:

'Yes, problem solving involves everything. To investigate, you are giving them a problem and they have to investigate. How many litres in a two-litre container? How many $250 \mathrm{ml}$ will you get from two litres? That's problem solving.' (Simone, Female, Grade 3 Teacher, 43 years old)

Her understanding of hands-on science was 'where they must go and do it themselves'. She explained that the teacher had to show and demonstrate and then the learners do it.

While Simone mentioned that she selected demonstrations, discussion, role-play, problem-based learning, cooperative learning and hands-on activities as instructional methods and used them daily, there was no evidence in Simone's lesson plans (numeracy and literacy) of such activities, except for small group teaching. The activity cited as an example of problem solving was a numeracy lesson on capacity in which Simone integrated measurement, which is a concept learnt in both numeracy and natural science. Once again, the activity cited as an example of hands-on science was a numeracy lesson in which Simone integrated measurement.

While hands-on science was indicated as a method often used, discussions with the teachers indicated that they had a very poor understanding of what problem solving, 
TABLE 5: Summary of the teachers' levels of interpretation of the natural science curriculum (Levels 1-4).

\begin{tabular}{lclcc}
\hline Participants & $\begin{array}{c}\text { Time } \\
\text { allocation }\end{array}$ & $\begin{array}{l}\text { Teaching natural } \\
\text { science }\end{array}$ & $\begin{array}{c}\text { Content } \\
\text { areas }\end{array}$ & $\begin{array}{c}\text { Instructional } \\
\text { methods }\end{array}$ \\
\hline Karen & 1 & 1 & 2 & 2 \\
Fiona & 1 & Between 1 and 2 & 2 & 2 \\
Carly & 1 & Between 1 and 2 & 2 & 2 \\
Simone & 1 & Between 1 and 2 & 2 & 2 \\
\hline
\end{tabular}

project-based learning and inquiry learning are. While they professed to apply these methods, deeper discussions revealed that the transmission method was dominant with limited demonstrations. It was also clear from the interviews that teachers chose the methods they used in general, rather than for teaching science specifically.

Based on the above findings, we placed the teachers on levels with regard to their interpretation of the natural science curriculum (Table 5). The selection of levels is based on the description in the composite table (Appendix 2).

\section{Conclusion}

Research has shown that teachers' content knowledge affects their confidence to teach science (Akerson \& Flaningan 2000; Appleton 2008; Waters-Adams 2006). Studies have shown that teachers experience insecurity with regard to their content knowledge when new content areas are introduced to the curriculum (Henze, Van Driel \& Verloop 2008; Lee \& Luft 2008). The teachers acknowledged that they were not confident to teach a number of science topics, limiting the number of topics they taught. This could have been the reason that the teachers in this study taught similar topics in every grade year after year. This situation is not unique to the South African context as research has shown that science is not given precedence at primary school level (Albion \& Spence 2013; Campbell \& Chittleborough 2014). This is particularly apparent in the foundation phase.

The findings also demonstrated the teachers' poor understanding of the meaning of integration. This is one of the major reasons why natural science in the foundation phase is taught poorly or not at all. Their interpretation of the curriculum stemmed from their understanding of a curriculum that consists of discrete subjects. From this viewpoint, the teachers believed that the curriculum did not offer sufficient opportunities to teach natural science, as they were unable to find links between topics included in literacy, numeracy and other areas of life skills. Because the teachers mainly used the Foundations for Learning documents as a resource and these lesson plans do not include natural science lessons, this influenced all the teachers' views of the importance of natural science. The absence of existing lesson plans (available to them) made it difficult for them to understand how this integration should occur.

The teachers were truthful in their responses when they said they did not teach much natural science. They are not specialist science teachers, so they were inclined to avoid teaching science. This type of action is found where teachers with poor subject knowledge in science often lead to neglect of the subject (Southerland et al. 2011; Tosun 2000; Tytler 2009). The teachers did not try to interrogate the curriculum to find ways of teaching science. While it is stated in the natural science curriculum that natural science should be taught, the Foundations for Learning documents do not cater for this. Teachers are happy to follow these documents, as they view them as expressing the views of the curriculum. Natural science is also neglected in the foundation phase because of the teachers' perception that precedence is placed on literacy and numeracy. This perception is not solely because of the teachers' views but the manner in which natural science is portrayed in the curriculum documents. There is no specific time allocated to natural science as it forms part of the life skills learning programme, which was also evident by the lack of teachers' life skills lesson plans.

The findings of this study highlight the importance of designing curricula that provide sufficient guidance for teachers, without which it becomes very difficult for teachers to interpret what curriculum developers had in mind when designing the curriculum. This is especially important in the case of foundation phase teachers who are generalists expected to teach all subjects. To teach science effectively requires knowledge of content and appropriate instructional methods. Furthermore, the curriculum needs to be supportive in terms of the time allocated to teaching science effectively, and if such a curriculum requires integration with other subjects, clear guidance should be given as to how this should occur. A curriculum that spells out exactly which topics should be taught as the CAPS (2011) currently does, as well as how these topics should be taught in a manner that develops learners' investigative skills, is essential.

\section{Competing interests}

The authors declare that they have no financial or personal relationship(s), which may have inappropriately influenced them in writing this article.

\section{Author's contributions}

S.B. collected data towards her PhD and prepared a draft of the findings. Her instruments were designed in collaboration with M.S. and A.J. M.S. extracted the section on teacher's interpretation of the natural science curriculum and prepared the article focusing on this aspect. A.J. refined and edited the article.

\section{References}

Akerson, V.L. \& Flaningan, J., 2000, 'Preparing pre-service teachers to use an interdisciplinary approach to science and language arts instruction', Journal of Science Teacher Education 11(4), 287-313. https://doi.org/10.1023/A: 1009433221495

Albion, P.R. \& Spence, K.G., 2013, 'Primary connections in a provincial Queensland school system: Relationships to science teaching self-efficacy and practices', International Journal of Environmental and Science Education 8, 501-520.

Appleton, K., 2003, 'How do beginning primary school teachers cope with science? Towards and understanding of science teaching practice', Research in Science Education 33(1), 1-25. https://doi.org/10.1023/A:1023666618800

Appleton, K., 2008, 'Developing science pedagogical content knowledge through mentoring elementary teachers', Journal of Science Teacher Education 19(6), 523-545. https://doi.org/10.1007/s10972-008-9109-4 
Australian Science, Technology and Engineering Council (ASTEC), 1997, Foundations for Australia's future: Science and technology in primary schools, Australian for Australia's future: Science and technol
Government Publishing Service, Canberra.

Beni, S., Stears, M. \& James, A., 2012, 'Teaching natural science in the foundation phase: Teachers' understanding of the natural science curriculum', South African Journal of Childhood Education 2(1), 63-81.

Campbell, C. \& Chittleborough, G., 2014, 'Promoting and improving the teaching of science in primary schools', The Journal of the Australian Science Teachers Association 60(1), 19-29.

Department of Basic Education (DBE), South Africa, 2011, Curriculum and Assessment Policy Statement (CAPS). Natural sciences and technology, Grades 4-6, Government Printer, Pretoria.

Department of Education for Northern Ireland (DENI), Northern Ireland, 2002, A survey of the science and technology area of study in a sample of Northern Ireland primary schools, 2000-2001, DENI, Bangor, Co. Down.

Fleer, M., 2009, 'Supporting scientific conceptual consciousness or learning in "a roundabout way" in play-based contexts', International Journal of Science Education 31(8), 1069-1089. https://doi.org/10.1080/09500690801953161

Garbett, D., 2003, 'Science education in early childhood teacher education: Putting forward a case to enhance student teachers' confidence and competence', Research in Science Education 33(4), 467-481. https://doi.org/10.1023/B:RISE. 0000005251.20085 .62

Goodrum, D., Hackling, M. \& Rennie, L., 2001, The status and quality of teaching and learning of science in Australian schools, Department of Education, Training and Youth Affairs, Canberra.

Hackling, M., Peers, S. \& Prain, V., 2007, 'Primary connections: Reforming science teaching in Australian primary schools', Teaching Science 53(3), 12-16.

Harlen, W., 2000, The teaching of science in primary schools, 3rd edn., David Fulton Publishers, London.

Harlen, W., 2008, 'Science as a key component of the primary curriculum: A rationale with policy implications', Perspectives on Education 1 (Primary Science), 4-18, viewed 12 October 2014, from http://www.wellcome.ac.uk/perspectives.

Henze, I., Van Driel, J.H. \& Verloop, N., 2008, 'Development of experienced science teachers' pedagogical content knowledge of models of the solar system and the universe', International Journal of Science Education 30(10), 1321-1342. https:// doi.org/10.1080/09500690802187017

Jansen, J., 2001, 'Image-ining teachers: Policy images and teacher identity in South African classrooms', South African Journal of Education 21(4), 242-246.

Kolokouri, E. \& Plakitsi, K., 2010, 'Scientific literacy and Nature of Science in early grades using cartoons', in G. Çakmakci \& M.F. Tașar (eds.), Contemporary science education research: Scientific literacy and social aspects of science, pp. 113-122, Pegem Akademi, Ankara, Turkey.

Lamanauskas, V., 2009, 'The importance of strengthening of natural science education in a primary school', Problems of Education in the 21st Century 11, 5-8.

Lee, E. \& Luft, J.A., 2008, 'Experienced secondary science teachers' representation of pedagogical content knowledge', International Journal of Science Education 30(10), 1343-1363. https://doi.org/10.1080/09500690802187058
Maphalala, M.C., 2006, 'Educators' experiences in implementing the revised national curriculum statement in the GET band', Doctor of Education thesis, University of Zululand, KwaDlangezwa.

Marques, M.E.B., Machado, P.J.C., Malheiro, M.T.M.C.M., et al., 2014, Creative little scientists: Enabling creativity through science and mathematics in preschool and first years of primary education, National report on recommendations for policy makers and stakeholders in Portugal, European Union Seventh policy makers and stakeholders in Portugal, European Union Seventh Framework Programme (FP7/2007-2013), EU Law and Publications, viewed 09
January 2017 from https://repositorium.sdum.uminho.pt/bitstream/.../D6\%20 6-NationalReport_PT_CLS.pdf

Petre, J., 2013, 'The use of living and non-living things during school practice in primary science education', New Educational Review 32(2), 255-263.

Rocard, M., Csermely, P., Jorde, D., Lenzen, D., Walberg-Henriksson, H. \& Hemmo, V., 2007, Science education now: A renewed pedagogy for the future of Europe, European Commission, Community Research, Brussels.

Rogan, J.M. \& Grayson, D.J., 2003, 'Towards a theory of curriculum implementation with particular reference to science education in developing countries', International Journal of Science Education 25(10), 1171-1204. https://doi.org/10. 1080/09500690210145819

Sachs, J., 2001, 'Teacher professional identity: Competing discourses, competing outcomes', Journal of Education Policy 16, 149-161. https://doi.org/10.1080/ 02680930116819

South Africa, Department of Education, 2002, Revised National Curriculum Statement, Grade R-9 (Schools) Policy, Natural Sciences, Government Printer, Pretoria.

South Africa, Department of Education, 2003, Revised National Curriculum Statement, Grade R-9 (Schools) teacher's guide for the development of learning programmes: Foundation phase, Government Printer, Pretoria.

South Africa, Department of Education, 2008, Foundations for learning: Assessment framework foundation phase, Government Printer, Pretoria.

Southerland, S.A., Sowell, S. \& Enderie, P., 2011, 'Science teachers' pedagogical discontentment: Its sources and potential for change', Journal of Science Teacher Education 22(5), 437-457. https://doi.org/10.1007/s10972-011-9242-3

Tosun, T., 2000, 'The beliefs of pre-service elementary teachers toward science and science teaching', School Science and Mathematics 100(7), 374-379. https://doi. org/10.1111/j.1949-8594.2000.tb18179.x

Tytler, R., 2009, 'School innovation in science: Improving science teaching and learning in Australian schools', International Journal of Science Education 3(13), 1777-1809. https://doi.org/10.1080/09500690802199889

Van Aalderen-Smeets, S.I., Van Der Molen, J.H.W. \& Asma, L.J.F., 2012, 'Primary teachers' attitudes toward science: A new theoretical framework', Science Education 96(1), 158-182.

Waters-Adams, S., 2006, 'Research report: The relationship between understanding of the nature of science and practice: The influence of teachers' beliefs about education, teaching and learning', International Journal of Science Education 28(8), 919-944. https://doi.org/10.1080/09500690500498351 


\section{APPENDIX 1: Questionnaire}

This questionnaire aims to understand your interpretation of the natural science curriculum within the foundation phase classroom. The information will be treated confidentially.

This questionnaire comprises eight sections (Sections A-D). Please answer all questions honestly by ticking $(\checkmark)$ the relevant column or writing your opinion in the space provided. Please complete all items. Thank you for being willing to complete this questionnaire.

\section{Section A: Personal details}

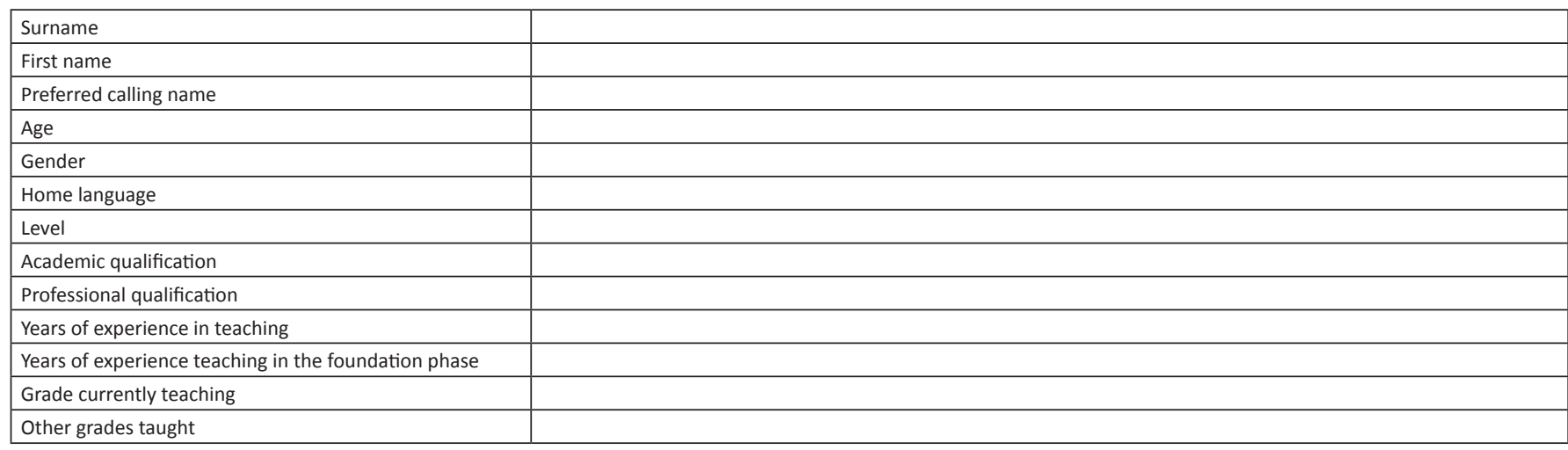

\section{Section B: Content knowledge}

1. Tick the science content that you believe that you can teach confidently. If you feel the list is incomplete, please add any topics to 'other' at the end of the list.

\begin{tabular}{|c|c|c|c|c|}
\hline Content topics & Very confident & Confident & Not so confident & Not confident \\
\hline \multicolumn{5}{|c|}{ Light energy and colour } \\
\hline \multicolumn{5}{|l|}{ Heat energy } \\
\hline \multicolumn{5}{|l|}{ Sound energy } \\
\hline \multicolumn{5}{|c|}{ Magnetic interactions } \\
\hline \multicolumn{5}{|l|}{ Electrical energy } \\
\hline \multicolumn{5}{|l|}{ Simple machines } \\
\hline \multicolumn{5}{|l|}{ Plants } \\
\hline \multicolumn{5}{|l|}{ Animals } \\
\hline \multicolumn{5}{|l|}{ Nutrition } \\
\hline \multicolumn{5}{|l|}{ Air } \\
\hline \multicolumn{5}{|l|}{ Weather } \\
\hline \multicolumn{5}{|l|}{ Water } \\
\hline \multicolumn{5}{|c|}{ Matter and materials } \\
\hline \multicolumn{5}{|c|}{ Reactions and changes of materials } \\
\hline \multicolumn{5}{|c|}{ Universe and solar system } \\
\hline \multicolumn{5}{|c|}{ Earth and moon systems } \\
\hline \multicolumn{5}{|c|}{ Human body (systems) } \\
\hline \multicolumn{5}{|l|}{ Matter and motion } \\
\hline \multicolumn{5}{|l|}{ Atoms } \\
\hline \multicolumn{5}{|l|}{ Ecology } \\
\hline Other & & & & \\
\hline
\end{tabular}

2. Which science content (from the list above) do you teach often? Why? 
3. Which of the science content (from the list above) have you never taught? Why?

\section{Section C: Instructional methods}

1. The following is a list of classroom methods. Please tick the box that most accurately describes how often you use these methods in your teaching of science topics. Please refer to the addendum, which will clarify what is meant by the instructional methods given below:

\begin{tabular}{|c|c|c|c|c|c|c|}
\hline & Daily & Weekly & Fortnightly & Monthly & Once a term & Never \\
\hline \multicolumn{7}{|l|}{ Inquiry } \\
\hline \multicolumn{7}{|l|}{ Lecture } \\
\hline \multicolumn{7}{|l|}{ Demonstration } \\
\hline \multicolumn{7}{|l|}{ Laboratory } \\
\hline \multicolumn{7}{|l|}{ Discussion } \\
\hline \multicolumn{7}{|l|}{ Role-play } \\
\hline \multicolumn{7}{|c|}{ Problem-based learning } \\
\hline \multicolumn{7}{|c|}{ Cooperative learning } \\
\hline \multicolumn{7}{|c|}{ Project-based learning } \\
\hline \multicolumn{7}{|l|}{ Discovery } \\
\hline \multicolumn{7}{|c|}{ Scientific investigations } \\
\hline \multicolumn{7}{|c|}{ Problem solving } \\
\hline \multicolumn{7}{|l|}{ Hands-on } \\
\hline \multicolumn{7}{|l|}{ Journal } \\
\hline \multicolumn{7}{|l|}{ Learning centres } \\
\hline \multicolumn{7}{|l|}{ Role-play } \\
\hline \multicolumn{7}{|l|}{ Scaffolding } \\
\hline \multicolumn{7}{|l|}{ Simulations } \\
\hline \multicolumn{7}{|l|}{ Case studies } \\
\hline \multicolumn{7}{|l|}{ Graphic organisers } \\
\hline Stories/narratives & & & & & & \\
\hline Other & & & & & & \\
\hline
\end{tabular}

2. Could you give reasons why you use the methods that you selected?

\section{Section D: Teacher factors}

1. The following is a list that could possibly describe you as a teacher. Please select the ones that could be used to describe you as a foundation phase teacher teaching natural science. You could include others if you so wish. Write a short paragraph to explain your choice.

\begin{tabular}{|l|l|l|}
\hline Dedicated & Confident & Conscientious attendance \\
\hline Caring & Approachable & Committed \\
\hline Well qualified & Tries innovative teaching techniques & Make an extra effort to improve teaching \\
\hline Experienced & Plans lessons well & Competent \\
\hline Attends professional development activities & Sound science content knowledge & Sound science pedagogical (teaching) content knowledge \\
\hline
\end{tabular}


2. What do you see as your greatest strength as a foundation phase teacher? Why?

3. What do you see as your greatest weakness as a foundation phase teacher? Why?

4. Have you attended any professional development workshops with regard to teaching natural science in the foundation phase in the last year? If you have, name them.

\section{Section E: General}

What proportion of the school day do you spend on each of the learning programmes, that is, literacy, numeracy and life skills?

\begin{tabular}{|l|l|}
\hline Learning programmes & Time (\%) \\
\hline Literacy & \\
\hline Numeracy & \\
\hline Life skills & \\
\hline
\end{tabular}

2. In what ways do you feel that your professional qualification and related field experience have best prepared you to be an effective foundation phase teacher?

Thank you for your cooperation

Addendum for Section C

Inquiry uses scientific reasoning and critical thinking to develop an understanding of science.

Lecture is direct instruction used to help students learn the concepts and skills.

Demonstration involves the teacher showing students a process or procedure such as a science process, a cooking procedure or a computer procedure.

Laboratory method is based on the principles 'learning by doing', learning by observation and proceeding from concrete to abstract.

Discussion is a combination of lecture and teacher questioning of students. It is designed to encourage thinking skills and allows learners to increase interpersonal skills.

Role-play deals with solving problems through action. A problem is identified, acted out and discussed.

Problem-based learning is a collaborative learning process that presents students with complex, real-world problems and provides guidance as they collaborate to develop content knowledge and problem solving skills.

Cooperative learning or group learning is an instructional strategy which organises students into small groups, so that they can work together to maximise their own and each other's learning. 
Project-based learning organises learning around projects. Projects are complex tasks based on challenging questions or problems that involve learners in design, problem-solving, decision making or investigative activities, give learners the opportunity to work relatively autonomously over extended periods of time and culminate in realistic products or presentations.

Discovery learning is an inquiry-based learning method in which learners use prior knowledge and experience to discover new information that they use to construct learning.

Scientific investigation is the process that can be defined in five words: observation, questioning, hypothesis, testing and explanation. These words, taken in this order, define the scientific method, the set of procedures biologists follow for sound and rational approach for proper practice of their discipline.

Problem-solving as a teaching method involves alternate ways of dealing with a problem and coming up with a previously unused or novel solution. It could involve integration of different learning areas.

Hands-on learning is learning by doing. Hands-on learning involves the child in a total learning experience, which enhances the child's ability to think critically. The child must plan a process to test a hypothesis, put the process into motion using various hands-on materials, see the process to completion and then be able to explain the attained results.

Journals are often used in classrooms to allow students to record reflections and ideas. Typically written in a notebook and recorded each day, the journal serves as a method of communication between the student and the teacher.

Learning centres are self-contained areas where students work independently or with small groups (pairs or triads) to complete a task. Centres may take the form of chairs placed around a table for group discussion, display boards that present questions/ problems/worksheets, or computer/computers where students perform hands-on activities or research on the web.

Scaffolding involves the teacher modelling the skill and thinking for the student. As the student increases understanding, the teacher withdraws the assistance allowing the student to take on more responsibility for the learning.

Simulations are used to put the student in a 'real' situation without taking the risks.

Case studies involve groups of students working together to analyse a 'case' that has been written on a particular situation or problem to find a solution.

Graphic organisers are found in the form of diagrams, maps and webs and illustrate information in a graphical format.

Stories/narratives as an instructional strategy are designed to convey abstract concepts through concrete experience. The narratives engage students in critical thinking and personal reflection. There is evidence that sharing ideas and concepts through story is an important way of encouraging social relations and helping students make connections between what they are learning in school and what they know of the world. 


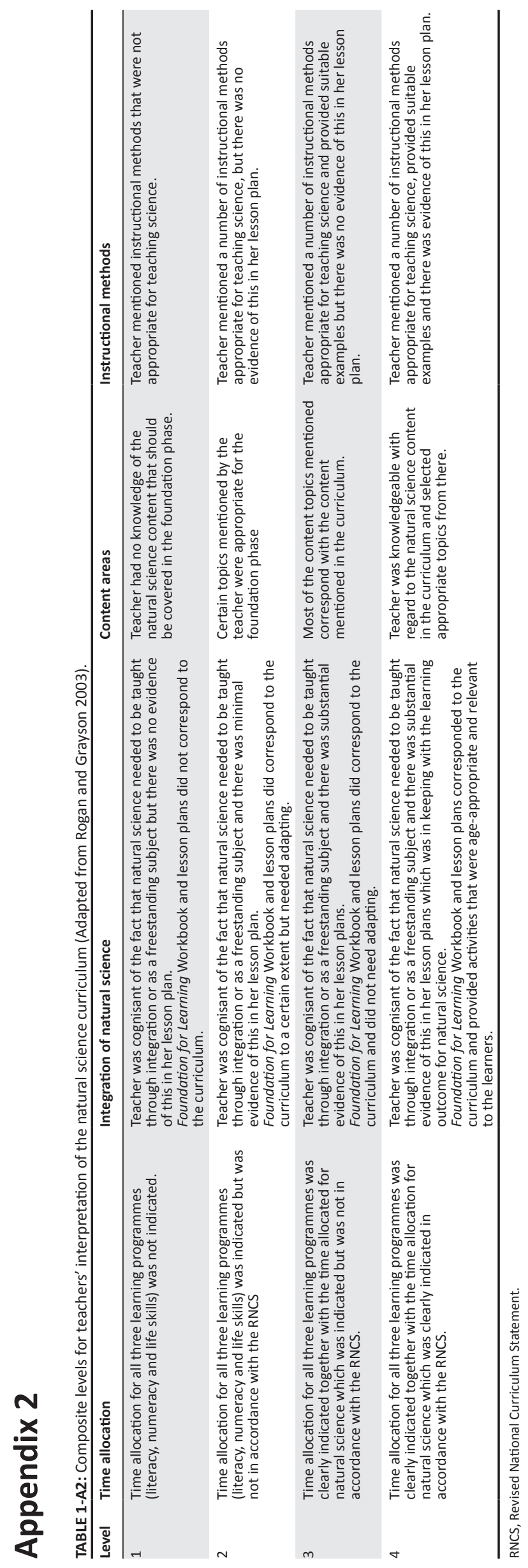

